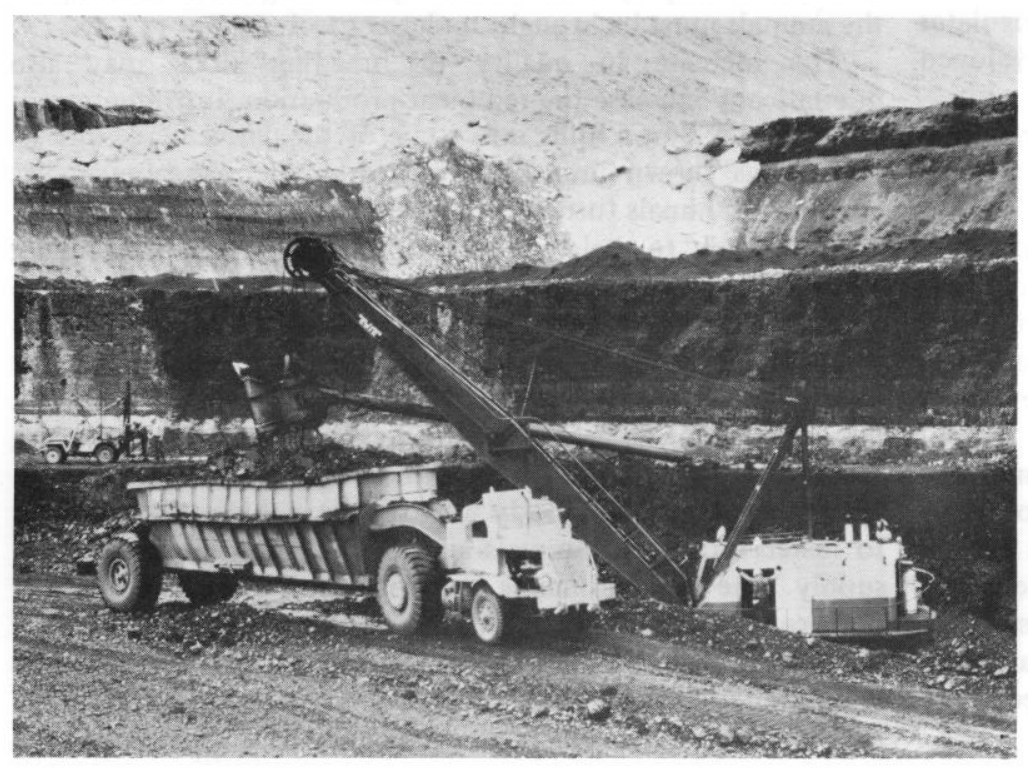

\title{
Surface Coal Mining in Wyoming: Needs for Research and Management
}

\author{
JOHN F. THILENIUS AND GARY B. GLASS
}

John F. Thilenius is a plant ecologist at the Rocky Mountain Forest and Range Experiment Station work unit at Laramie, Wyoming, in cooperation with the University of Wyoming; central headquarters maintained at Fort Collins, Colo., in cooperation with Colorado State University. Gary B. Glass is the staff coal geologist with the Geological Survey of Wyoming in Laramie.

Manuscript based on a talk by Thilenius to a joint meeting of Colorado Sections of the Society for Range Management and the Wildlife Society, Denver, Colorado, December 6, 1973.

Manuscript received March 20, 1974.

Highlight: Wyoming ranks second in the nation in strippable coal resources, with at least 18.9 billion tons of coal presently recoverable. Mining this coal could disturb about 590 square miles (0.6\%) of the state's land area. The presence of this disturbed land offers a challenge to, and opportunity for, the varied fields of renewable resource research and management to practice their sciences and arts to allow the nation to use the coal without lasting detrimental effects on other resources. 


\section{Location and Quantity of Coal}

In 1902, the Hon. Fenimore Chatterton, Wyoming Secretary of State, made the following statement:

"Coal? Wyoming has enough with which to run the forges of Vulcan, weld every tie that binds, drive every wheel, change the North Pole into a tropical region, or smelt all hell!"

While today this kind of bombastic rhetoric may be in disfavor, there is little doubt Fenimore Chatterton was correct. Present estimates are that between 0 and 6,000 feet below the surface of some 40,000 square miles of Wyoming are over 545 billion tons of coal (Table 1). This is $17 \%$ of the total coal present in the United States and ranks Wyoming first among the states in total coal resources. Only a very small fraction of this coal has been mined (Table 2).

Of this, $25 \%$, or 136 billion tons has actually been mapped. The coal which has been mapped is within 3,000 feet of the surface. Approximately $2 \%$ is lignite, $88 \%$ is subbituminous, and $10 \%$ is bituminous coal. These three classes of coal increase in heat value from lignite to bituminous.

One half of the mapped coal in Wyoming is considered recoverable, with $17 \%$ classified as a strippable resource. This is more than $20 \%$ of the nation's known strippable coal and ranks Wyoming second only to Montana. Almost $80 \%$, or 18.9 billion tons, (1) occurs in seams with a minimum thickness of 5 feet, (2) underlies overburdens ranging from 20 to 200 feet, and (3) has stripping ratios (ratio of overburden to coal) bctwcen 1:4 and 10:1. These seams are mineable under present technology and economics. Approximately 236 square miles of pit acreage $(151,000$ acres) or about $0.2 \%$ of the state's land area could be disturbed if all this strippable coal were mined. When the additional acreage affected by spoils, roads, buildings, etc., is added to the pit acreage, the total disturbed acreage increases to 590 square miles.

There are 10 major coal-bearing regions in Wyoming (Fig. 1 ), but the majority of the strippable coal is located in only five (Table 2). Almost $90 \%$ of the strippable coal reserves are in the Powder River Basin of northeastern Wyoming. The Hams Fork and Green River regions in southwestern Wyoming each contain over $4 \%$. The remaining $1.2 \%$ is in the Hanna Field and Bighorn Basin.

Table 1. Remaining strippable coal reserves (tons) in major Wyoming coal-bearing regions as of January $1,1973 .^{1}$

\begin{tabular}{lccr}
\hline & \multicolumn{3}{c}{ Strippable area ${ }^{2}$} \\
\cline { 2 - 4 } Coal region & Coal reserves & $\begin{array}{c}\text { Square } \\
\text { miles }\end{array}$ & \multicolumn{1}{c}{ Acres } \\
\hline Powder River Basin & 17 billion & 110.3 & 70,560 \\
Green River Region & 921 million & 92.1 & 58,935 \\
Hams Fork Region & 793 million & 20.0 & 12,800 \\
Hanna Field & 214 million & 13.1 & 8,400 \\
Bighorn Basin & 2.4 million & $>0.1$ & 42 \\
\multicolumn{1}{c}{ Total } & 18.9 billion & 235.6 & 150,737 \\
\hline
\end{tabular}

${ }^{1}$ Modified from Smith, 1972.

${ }^{2}$ These estimates are only the pit acreages. Currently, 2.5 times the pit acreage is disturbed in extraction of the coal when spoils, roads, building, tipples, etc., are added to the pit acreage.

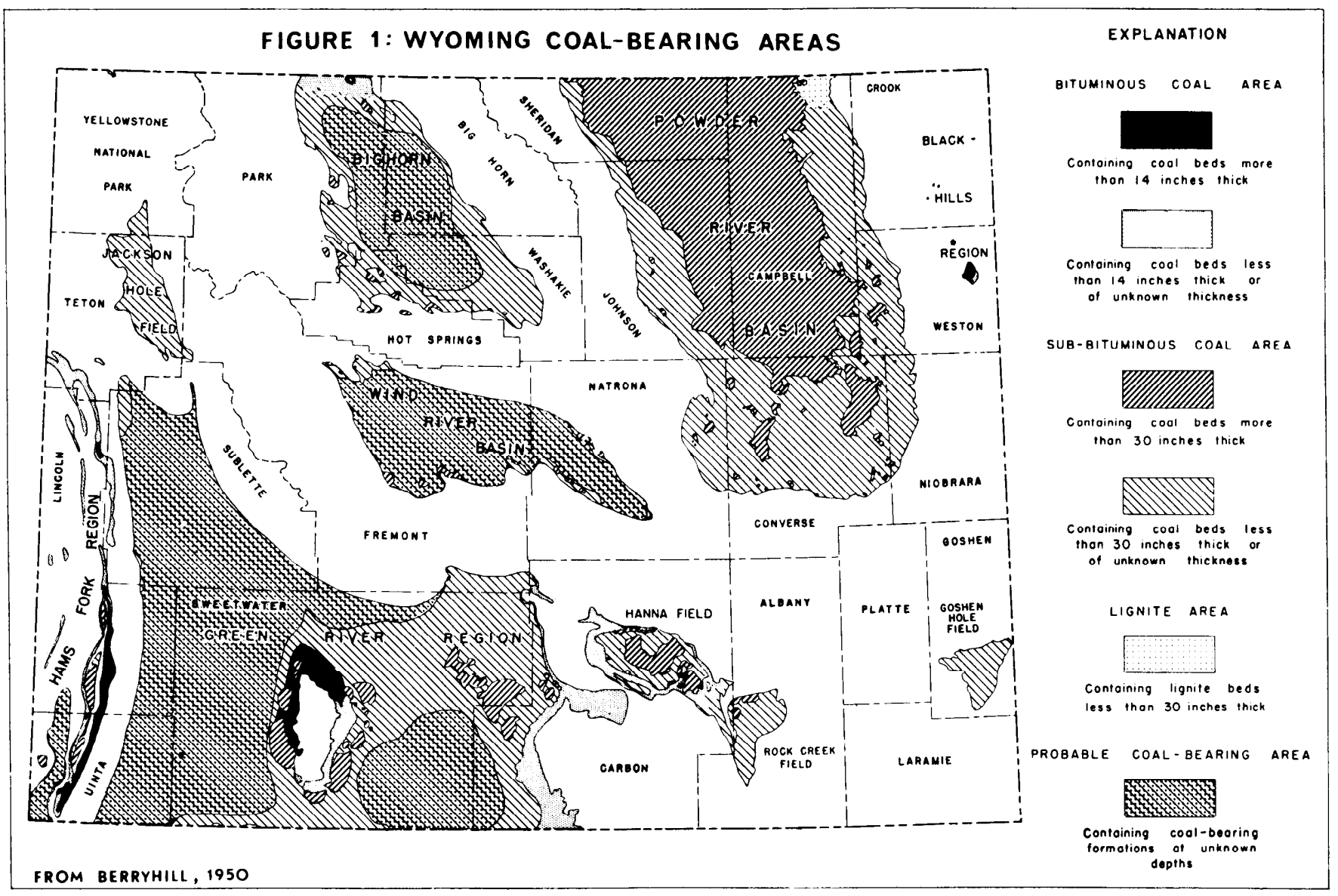

Fig. 1. Wyoming coal-bearing areas. 
Table 2. Estimates of remaining Wyoming coal resources (billions of tons) as of January 1, 1973.

\begin{tabular}{lcc}
\hline \hline & $\begin{array}{c}\text { Mapped and } \\
\text { explored } \\
(0-3000 \mathrm{ft})\end{array}$ & $\begin{array}{c}\text { Mapped and } \\
\text { unexplored } \\
(0-6000 \mathrm{ft})\end{array}$ \\
\hline Resource & 136.89 & 545.71 \\
Original coal resource $^{1}$ & & \\
$\quad$ Production of coal ${ }^{2}$ & -0.38 & \\
$\quad$ Underground mines & -0.08 & \\
$\quad$ Strip mines & -0.46 & -0.46 \\
$\quad$ Total production & & \\
Losses due to mining & -0.38 & \\
$\quad$ Underground mines (50\% recovery) & -0.02 & \\
$\quad$ Strip mines (80\% recovery) & 0.40 & 0.40 \\
$\quad$ Total losses & 136.03 & 544.85 \\
\hline
\end{tabular}

${ }_{1}^{1}$ Source: U.S. Geological Survey and U.S. Bureau of Mines.

${ }^{2}$ Source: U.S. Geological Survey, U.S. Bureau of Mines, and Wyoming State Inspectors of Mines.

There are 23 coal seams currently being mined in Wyoming. They range from less than 4 feet to 118 feet in thickness. Seams mined underground are usually thinner and average about $8 \frac{1}{2}$ feet thick. Surface-mined seams average 32 feet. The thickest seams occur in the Hams Fork Region and the Powder River Basin. Another coal seam, 220 feet thick and perhaps the thickest coal seam in the world, occurs just east of Buffalo, Wyo.

Coal seams in the eastern and southern United States are generally much thinner, and much more land must be disturbed to obtain an equal tonnage of coal. However, heat values of eastern coal average $1800 \mathrm{Btu} / \mathrm{lb}$ greater than the average Wyoming coal.

Eastern coals are also normally higher in sulfur, leading to the much-publicized acid water problem and to atmospheric pollution with sulfur dioxide. Overall, $96 \%$ of the strippable coal in Wyoming contains less than $1 \%$ sulfur. The ash content of Wyoming coals (another attribute important in air pollution) is also low, averaging only $7.6 \%$.

\section{Mining Activity and Methods}

Coal has been mined in Wyoming since about 1865 . Underground mines have accounted for nearly $83 \%$ of the total production. Annual surface-mined coal tonnage did not exceed that of underground mines until 1954. Since then, surface mine production has increased more than seven-fold and constituted $96 \%$ of the record annual production of 10.9 million tons set in 1972. Within the next 8 years, surface mines should produce as much coal as was mined in over a century of underground mining.

Current estimates indicate underground mines will continue to account for less than $4 \%$ of Wyoming's annual coal production for the next 25-30 years. Strict new regulations limiting or banning surface coal mining could alter this. Most of Wyoming's strippable coal deposits are too thick and have too little overburden to be efficiently mined by underground methods.

Currently, 12 of the 16 active coal mines in Wyoming are surface mines. These surface mines are of two types: open-pit (or area mines) and contour strip mines. Both types are about equally represented at present, but open-pits are likely to predominate in the future. Contour stripping tends to disturb more land than open-pit mining, because the cut is long and narrow in contrast to the more or less equilateral excavation of the open-pit operation. An open-pit mine is particularly adaptable where the coal seam is thick and flat, and the overburden thin. Contour stripping is most adaptable where a seam is thinner and more steeply dipping.

\section{Uses of Wyoming Coal}

Almost 93\% of Wyoming's coal production presently is consumed by steam-generated electric power plants. The sugar beet, cement, and synthetic coke industries, and domestic users utilize smaller amounts.

Although Wyoming coal is relatively low in heat value, it is suitable for power plants because, (1) it is very abundant and can meet fuel supply demands; and (2) it is "clean", that is, low in sulfur, and can meet air pollution standards.

Gradually, the use of coal for power generation will become less important as nuclear power and other more exotic energy sources are developed. Greater utilization and demand for coal in the petro-chemical industry as a source of carbon-based compounds is likely in the future.

Another use of Wyoming coal will be conversion to gaseous and liquid fuel. Because larger quantities of water are needed, a shortage of industrial water in Wyoming's coal-rich regions may be the greatest limiting factor in the conversion of coal to synthetic fuels.

Water use projections for the requirements of a synthetic fuel industry in the Powder River Basin are as high as 2.2 million acre-feet a year by 1990 . The current estimate of available industrial water that could be diverted into the area is 832,000 acre-feet a year-a considerable difference. The development of industries based on Wyoming coal resources would mean a large and concomitant development of water resources with their manifold attendant environmental problems. The effects of atmospheric pollution and the social and economic problems (housing, transportation, sewage disposal), which may arise from rapid and intensive industrialization of a basically rural State, are also major problems which would need to be solved.

\section{Reclamation Laws in Wyoming}

Prior to 1969 , Wyoming had no laws requiring mine spoils to be reclaimed. In 1969, the Open Cut Land Reclamation Act became law. It applied to the surface mining of all mineral resources in Wyoming, including those on federal land, but excepting Indian land. This Act required for reclamation:

-surety bonding equal to reclamation costs;

- minimum guidelines for grading;

-reseeding required whenever "practicable";

-an annual report of reclamation (including a map); and

-liberal timing requirements for reclamation-these were

left to the State Land Commissioner's discretion.

Under the Open Cut Land Reclamation Act, the coal companies reported they had rehabilitated nearly one-half the surface acreage affected between 1969-71. About $29 \%$ of the total surface acreage disturbed by surface coal mining prior to 1971 is considered by the state to have been rehabilitated under the minimal standards of the 1969 Act. The 1969 Act did not require rehabilitation of land disturbed prior to its enactment.

In 1973 a new law was passed, entitled the Wyoming Environmental Quality Act of 1973. It is designed to regulate land development and control the pollution of air, water, and land within the state. The 1973 Act pertains to all types of 
underground mining as well as surface mining. It does not regulate oil or gas operations, which are under a separate law. Some of its more important features with regard to rehabilitation are:

1) It repeals the 1969 Act.

2) It establishes a 9-man board to administer the Act in place of the Land Commissioner. This board is appointed by the Governor.

3) It requires issuance of an operator's license and mining permits and sets provisions for dental of permits.

4) It requires advertisement of mining permit applications, and provides for filing objections to the application and public hearings.

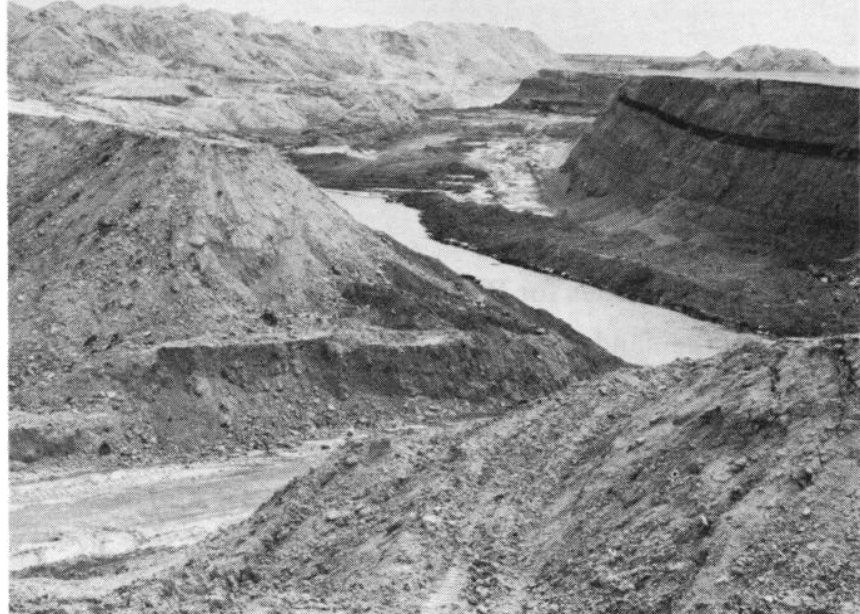

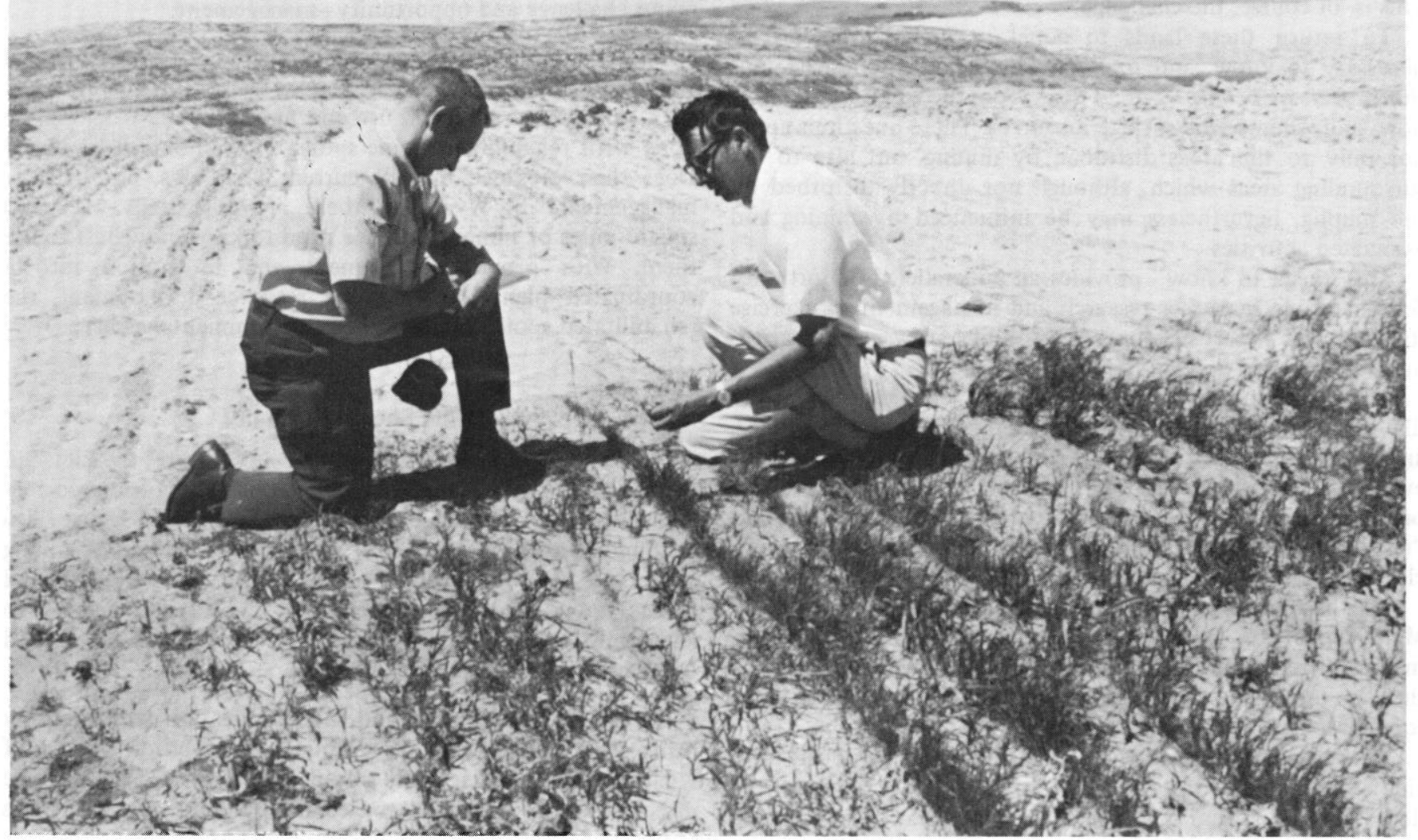

5) It requires land disturbed by mining to be returned to a use of equal or greater value than its prior use.

6) It requires a mining plan showing the nature and extent of the mineral resources, the land to be mined, and a description of the mining operations, with a time schedule.

7) It requires a reclamation plan prior to the issuance of a mining permit. This plan must include:

a) cost estimates for reclamation;

b) maps showing extent of reclamation, which must be periodically updated;

c) methods of stockpiling, preserving, and returning the topsoil;

d) methods of regrading and recontouring the affected land; and

e) methods and plants used for revegetation.

8) It requires the prevention of water pollution from mine spoils.

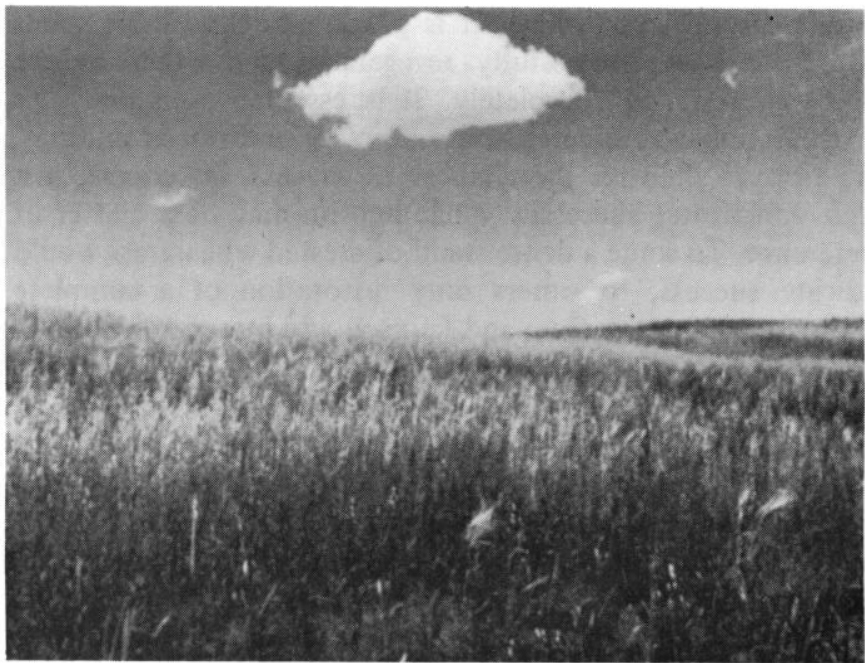


9) It sets time limits on reclamation, and can raise the surety bonding requirements.

10) It requires the consent of the surface owner (if different from the mineral owner) to both the mining and reclamation plans.

\section{Opportunities for Research and Management}

Most of the land which overlies the rich coal seams of Wyoming is rangeland in the truest sense of the word. It has, in the past, been considered to be of low economic value, and used as range for domestic livestock and wildlife.

Now, an acre of this land, which was valued at $\$ 3.00$ to $\$ 50.00$, may have from $\$ 50,000$ to $\$ 220,000$ worth of coal beneath it. One needs only to get rid of the "low value land" on top of the coal. However, the law in Wyoming now requires the overlying "low value land" to be put back so it is "returned to a use of equal or greater value than its prior use." This is, of course, the challenge.

To return these lands to equal or greater value, it is necessary to know, and to know should be emphasized-not think, feel, or believe-a great deal about the what, where, why, how, and when of the surface resources. These questions apply not only to the areas disturbed by mining, but also to the surrounding areas which, although not directly disturbed by the mining, nevertheless may be influenced by mining and associated activities.

This "need to know" provides an unparalleled opportunity for renewable resources rescarch and management to exercise its skills and expertise. The opportunities are vast and varied, in both basic and applied fields.

For example, it is necessary to know what these lands are like prior to mining with regard to their soil, vege tation, water, and animal resources. Then changes wrought by mining can be evaluated, and standards from which to measure the success, or failure, of rehabilitation efforts can be developed. This "need to know" will require a strong program of ecological classification and detailed resource inventory.

The basic ecology of the mine spoils must be understood. Mine spoils are, in reality, new ecosystems; their environmental attributes and ecological processes must be known if they are to be successfully rehabilitated and eventually utilized to yield renewable resource products.

Methods and technology of rehabilitation obviously provide a vast area for research. One hears, or reads, "it can't be done!" or "there's no problem." The real situation most likely lies somewhere between: certain sites may be easier, or harder, to rehabilitate than others. It is possible to find mine spoils that have been successfully revegetated and others where revegetation failed completely. It is essential to know why rehabilitation was successful in one place and not at another, and how to increase the chances of success. Of course, just what constitutes successful rehabilitation may be a matter of preference. To some a dense stand of crested wheatgrass would indicate success; to others only restoration of a complete community of native flora and fauna would be acceptable.

There is much to be learned about the relationships between mining activities and wildlife. What is the influence of surface coal mining on composition, density, and movements of wildlife populations? There is little doubt that surface mining may directly destroy many animals, especially those which live in the earth, or lack ability to migrate easily. Animals may also be indirectly eliminated from the mined areas by the destruction or severe alteration of their habitat.
But are these changes permanent?

Successful rehabilitation of mine spoils can lead to habitat diversification as new ecosystems are being introduced. How will this rehabilitation influence animal populations? Will they occupy or use the spoil areas, if so why, which ones, how much, and when? If wild herbivores are attracted to these areas, how will they influence plant development, growth, and succession? Deer have been observed ruminating less than 100 yards from a location where 75-ton-capacity trucks were dumping overburden at a rate of about one truck every 4-5 minutes, and antelope commonly graze revegetated spoil areas in the middle of ongoing mining operations. This does not mean mining has no effect on deer or antelope or their habitat, but the effect may not be entirely detrimental. We need to know how serious the effects are. Similar questions might be asked about the influence of domestic animals on the spoils. Finding answers to these questions leads to what may be the major challenge and opportunity-management.

What about the management of these areas? Specialists in renewable resources certainly should be looking carefully at their possible or potential use and management. What can be done with rehabilitated mine spoils? How should it be done? Does their presence modify current land uses, products, or management? In Wyoming, there are potentially over 500 square miles of mine spoils. We need to know how best to use them. With proper management and integration into a coordinated plan for renewable resource development, the rehabilitated spoils can become an environmental asset.

\section{What Should Be Done?}

All of what has been said before has been "after the fact," in other words, what needs to be done after mining has occurred. Specialists in renewable resources should and must also become directly involved in the planning and design of mining operations. If the problems of rehabilitation are considered before they take place, the costs and efforts needed to accomplish successful rehabilitation could be decreased, and the chance of successful rehabilitation increased.

Increased coal mining and industrialization will naturally bring about an increase in the human population density of what is now a very sparsely populated part of Wyoming. The direct study of the social and economic consequences of this are obviously within the province of other disciplines. Nevertheless, increased human density and activity will certainly have many effects on renewable resources and these effects will extend far beyond the actual mined areas. Effects may be direct, such as the loss of habitat to housing and utility and transportation systems; or indirect because of increased recreational or aesthetic needs of the people. The renewable resource specialist should and must be involved from the start in this phase of the problem if the detrimental effects of these impacts are to be minimized or avoided and management plans devised which incorporate the new or increased needs of the pcople.

Only a few of the problems where specialists in renewable resources can and should become involved in surface mining of coal have been considered. There are many others, and there are many renewable resource specialists already involved. The need to become involved is urgent. Coal from Wyoming and other western states is being mined now, and this mining will 
be greatly expanded in the near future. This coal seems necessary and essential for the nation's continued existence and prosperity. However, the necessity for using the coal does not confer any right to exploit or permanently degrade or destroy other resources in the process.

At present, it is still possible to be optimistic that surface mining rehabilitation can be achieved. Simply because past surface mining of coal has in some areas led to environmental degradation and destruction, it does not inevitably follow that such degradation cannot be avoided. The varied specialists in renewable resources research and management have a tremendous opportunity to practice their sciences and arts to allow the nation to use one major and very important resource without lasting detrimental effects on other resources.
Very soon we must reach the stage where we stop talking about doing something, and arguing about how to do it, and start doing it. We are already behind. The mine spoils are there now, and there will be more of them soon.

\section{References}

Berryhill, Henry L., Jr., Donald M. Brown, Andrew Brown, and Dorothy A. Taylor. 1950. Coal resources of Wyoming. U.S. Geol. Circ. $81.78 \mathrm{p}$.

Glass, Gary B. 1973. Wyoming-the energy state: Coal Age. Western Coal Edition. 78(5):186-212, mid-April.

Smith, Joseph Blake, Maynard F. Ayler, Clinton C. Knox, and Benjamin C. Pollard. 1972. Strippable coal reserves of Wyoming. U. S. Bur. of Mines, Inform. Circ. 8538. 51 p. 